\title{
Role Of Women In International Business, Management And Trade
}

\author{
Farrukh Naseem Qureshi \\ Shaheed Zulfiqaar Ali Bhutto Institute of Science Technology \\ Tehreem Farrukh \\ School of Law \\ University of Karachi
}

\begin{abstract}
Gender balance is progressively observed as useful for business. The developing cooperation of women in the work has been a significant vehicle of worldwide development and aggressiveness. The discriminatory constraint keeps women from arriving at top positions in business, however women can contribute and add additional boost to the growth and sustainability of the economies. Countries which are open to female contribution in the economy are more economically sound. In this article Qualitative technique has been used and findings reveal that women should be given equal opportunity to create women's economic empowerment and create an inclusive system.
\end{abstract}

Keywords: Gender, International Business, Women, Gender Equality, Entrepreneurship, Management.

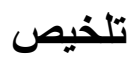

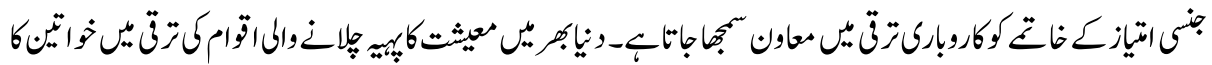

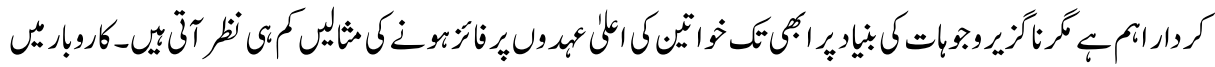

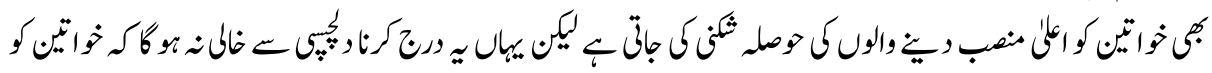

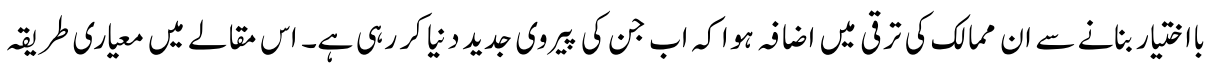

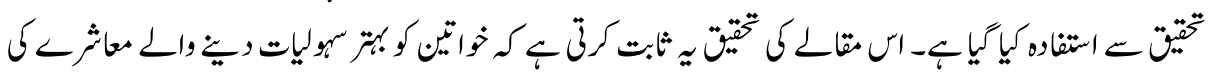

$$
\begin{aligned}
& \text { معيثت مضبوطنونقب }
\end{aligned}
$$

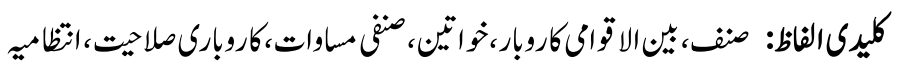

\section{Introduction}

At present, people are living at the junction of three tectonic shifts: digital revolutionary phase; an environment-based revolution; and a social revolution (Carter, Simkins \& 
Simpson, 2013). Altogether, worldwide economy and business is witnessing surfacing of different themes that were never in the frame in former decades. After decades of narrowly focusing on setting regulation for capital flows, goods and servicesenvironmental and social issues have been transpiring up the agenda. Amongst which, the prime focus has been on gender equality for women and their role in emerging global economy.

It is evident in many studies that women have become drivers for financial growth within nations and across the globe. Great thinkers and philosophers have encouraged the position of women in government, media, trade, and business - even when the gender equality remains a significant distance away. Economies in Eastern Europe (37 percent) and Southeast Asia (35 percent) direct the way on females in the sphere of leadership (Joy et al., 2007). Across the Globe, Russia has the leading percentage of females in top management positions. It is a proportion (43\%) that has been stable since 2004, aided by a gender ration that supports females by 6:5. To a different place in East Europe, the Baltic areas of Estonia (39 percent), Georgia and Armenia (together 35 percent) and Poland (34 percent) are all well above the worldwide average. It can be dated back to the advancement of females in the former Soviet Union (Noland, Moran \& Kotschwar, 2016).

The UN Goals for Sustainable Development are acknowledged by 193 nations of the world and among them, Goal 5 aims to prioritise the need to end gender discrimination against females in all types. UN Goal 5 is Gender Equality, which focuses on highlighting the role of women in areas like health, education, and business. While females' empowerment is a precondition - so far as it is a result - for attaining the International Business Goals, much of the debate on gender has stressed on attaining UN Goal 5, in some manners casting females as recipients of the Goals. The key aim of this report is to demonstrate that females do not just serve to benefit from the achievement of the Goals; they are also aiding to direct their success. This brief paper meant to address every woman and encourage them to step ahead and lead for the UN Goals, irrespective of their spheres of interest.

Women can contribute and can be a source of boost to the growth and sustainability of the economies. Countries with equal opportunities for women and open to female contribution are more competitive and economically sound. Economic empowerment of women is imperative for growth and productivity. The increase in female income will increase the better education for their children who are the future of economy. The women's income is directly related with the future growth by its impact on education (IMF, 2018).

Gender-based isolation is inescapable overall and joined by sex wage holes (UN-Women, 2015a). Particular ideas of "men's work" and "women's' work" will in general isolate 
women in labour-serious enterprises, for example, pieces of clothing, materials, light gadgets and toys, while men are all the more effectively found in aptitude and capitalconcentrated areas. Due to frequently bring down degrees of aptitudes and training, lower versatility and time neediness, women are more probable than men to be associated with low wage trades and businesses. Moreover, gendered generalizations have fortified the picture of women labourers as easy going and appropriate for redundant and nitty-gritty work (UNCTAD, 2014; Caraway, 2007).

In some societies conducting research on gender and specifically women is difficult which leaves no space for researchers to depend upon the secondary data.

\section{Review of Literature}

\section{Gender Equality and International Trade Policies}

Global trade intermingles with gender equality in different manners, and its impact is not always neutral (Elliott, 2016). The differing impacts of international trade on gender equality are habituated by the different roles of females and males in the financial sphere. Realising the social and economic gaps between both genders, the most current trade policies take account of gender provisos as a way to support the financial empowerment of females (GIZ, 2014). In a few cases, gender-based conditions are incorporated to support equal opportunity, and there are also programs to mainstream a gender viewpoint into universal trade policies, and into support mechanisms for the exporting industry (Epstein \& Coser, 2018).

The collectivist leaders assured 'equality for all' and it is best reflected through the development of females in rapidly growing industries like healthcare, education, and finance (McElhaney \& Mobasseri, 2012). In East Asia, the comparatively high percentages of females in top management positions can partially be outlined by the tendency for family circles to live near to grandparents. This provides free, built-in childcare services, letting mothers work easily (Noland, et al., 2016). Females in Indonesia (41 percent), the Philippines (40 percent) and Thailand (38 percent) all enjoy the support they get from their family units. In China, females are also well-represented in the leadership roles (38 percent); in the same manner, the focus of communism in Russia is to promote gender equality and it plays a central role to play in (De Vita, Mari $\&$ Poggesi, 2014). The country has introduced a one-child policy that has decreased the child care burden and led to quick urbanization.

Gender equality is one of the Sustainable Development Goals (SDG) of the UN 2030 Program to which countries, business enterprises, civil bodies and other players of the global society have shown dedication and absolute commitment. Gender is a cross- 
cutting theme among the other 17 objectives of the SDGs. As suggested by Bencko \& Pelster (2013), without gender equal opportunity SD is not possible. There are many examples of the current integration of gender provisos in trade policies (Cook \& Glass, 2014). The Asia Pacific Economic Cooperation is a powerful forum that has pioneered in integrating the issue of gender within its main agenda. More currently, in 2016 the trade and business contract between China and Uruguay was the first to consider a separate section on gender and trade.

The Addis Ababa Action Program of 2015 forms an integral element of the 2030 program. It develops a particular linkage between trade and gender equal opportunity (World Health Organization, 2014). As per the World Health Organization (2014), the critical role of females, as manufactures and trade partners, and the need to overcome their particular challenges in order to support their equal and proactive involvement in local, regional and global trade policies. In 2017, 118 member states and viewers of the WTO (World Trade Organisation, 2017) agreed to the declaration on gender and trade. Measures to supports females' export entrepreneurship have also been initiated in different national and local trade policy programs in America and the Caribbean. In a few cases, the advocacy of global development collaboration has been useful to this point.

The different roles of females and males in financial activity also condition the differing impacts of global trade activity (GIZ, 2014). Trade influences females through communication mediums. These channels are 1) work (job, income, pay-gap, work environment); 2) free enterprise (access to financial resources and information asymmetry), 3) consumption patterns, 4) allotment of financial means for the proviso of social services, and 5) roles in house as care takers (Jobes, 2010 \& GIZ, 2014).

\section{Trade Liberalisation Policy}

Determining the particular gender impacts of trade is hard because of poor genderdisaggregated data relating to employment, wage, and other financial measures. In the situation of females' export entrepreneurship, there is a lack of useful data and insight. Development in the disaggregation by gender of regional and global financial figures has been quite slow, regardless of the bilateral promises on this matter made over twenty years before at the Women Round Conference in Beijing in 1995 (Bollen, 2018). In spite of such problems, different studies have highlighted these impacts, using unique methods. Some of them are gender equal opportunity elasticity (van Staveren, 2007), social accounting frameworks (Bussolo \& de Hoyos, 2009), and general balance model with sex-based variables (Friel et al., 2013).

Many studies prove that the impact of trade on females is indistinct and varies between industries, areas, social, economic and education levels. On the one side, trade 
liberalisation policy can bring in more export activities along with the creation of new jobs and income levels. This eventually facilitates the woman empowerment in the international business (Friel et al., 2013). On the other side, this opportunity also improves import activities, which can adversely impact female employment along with different local industries. The total impact of trade liberalisation policy is vague and unclear.

The trade impact on developing nations of the world differs by sector and geography. For instance, trade development might aggravate gender differences in agricultural economies like Africa. However, it can decrease them in markets with a significant production sector like Honduras (Bussolo \& de Hoyos, 2009). Sex-disaggregated information on employment, which is readily accessible, proves just a biased angle of the interface between sexual category and trade (Carter, Simkins \& Simpson, 2013). It is essential to create quantitative as well as qualitative data to evaluate the gendered impact of trading activities across different transmission (communication) mediums recognised above (employment, free enterprise, consumption pattern, social amenities, and role in houses as care service providers), and not just through data on female's employment and wage levels (Lippoldt, 2013).

\section{Importance of Women in International Trade and Business}

Gaining gender diversity is considered as essential for cutthroat business performance with facts proving that involvement of women at all levels of business operations and management greatly improves bottom-line (Bussolo \& de Hoyos, 2009). The relationship between females in $\mathrm{C}$-level managerial positions and positive business performance has been researched repetitively. A number of studies of females on corporate boards assessing Fortune 500 and 1,000 businesses, and a grand sample of American and European companies, demonstrated how business entities with increased shares of female executives and leaders performed extraordinarily (De Vita, Mari \& Poggesi, 2014). Such companies have shown an average increment in ROE (return on equity) of 53percent, along with $42 \%$ high profit margins and $66 \%$ high returns on invested capital (Cook \& Glass, 2014).

One study also revealed that having at least three females on the board generates the best outcomes. A panel of a board or C-suite comprised of 30\% females can improve profit margins by $15 \%$ contrasted with firms with no female leadership and get a net profit increment for both profitable and unprofitable companies of $6 \%$ points (Noland, Moran, $\&$ Kotschwar, 2016). One more study discovered that there was a $20 \%$ low insolvency rate for business firms with at least one female on the C-suite level (McElhaney \& Mobasseri, 2012).

The disparity in the pay level of both genders is particularly intense in the financial activity, and, keeping into consideration current trends, this is where the gap will take a long time to seal. As per the International Gender Gap Index of the Worldwide Economic 
forum, at the existing rate, female's financial contribution and opportunities gap will end just in 219 years (Bencko \& Pelster 2013). Gender disparity not just brings serious implications with respect to social fairness and individual respect but also minimizes financial development competitive strength. The OECD projects that the financial losses generated by gender inequality can reach 11,750 billion dollars or 16 percent of worldwide income in 2016 (De Vita Mari and Poggesi, 2014). By incorporating a gender viewpoint, trade policy can greatly contribute to enhance opportunities for females and decrease such losses.

\section{Female Entrepreneurship and Global Trade}

Small and medium sized companies bring in more or less 50 percent of international GDP and 70 percent of total employment. The advantages of trade to small and mid-sized companies and female-run companies are noteworthy - and so are the gains to the broad economy from better involvement in global trade by small and medium enterprises and females. As per the research was done by McKinsey, the consultancy, promoting females' parity can add 28 trillion dollars to the worldwide GDP by 2025 - equal to adding a newfound USA and China (Bussolo \& de Hoyos, 2009). In the current times, on the other hand, the ITC report proposes that females are just responsible to run one in five exporting enterprises (Papadopoulos \& Heslop, 2014).

Trade liberalisation has had a remarkable impact on the figure of females working in the manufacturing industries of developing nations of the world (De Vita Mari and Poggesi, 2014). As per ILO, export-focused industrialisation is related to an increasing share of female manufacturing employment - mainly in the textile sectors, clothing, and electronics industries. Some $70 \%$ to $90 \%$ of the employees hired in export processing areas are female (WEF, 2017). They also generate more than half of the globe's domestic products and their percentage of casual employment usually matches or goes further than males. In the more conventional agriculture business, the FAO has predicted that females might generate over half of the globe's foodstuff. As financial performers, females use their pocketbooks along with different skill levels - they are important customers and makers as well (Davies, 2016). As clients, they generally make buying decisions for themselves and their families, multiplying the financial impact of their choices.

\section{Quality of Business Leadership in Women-Driven Business}

Diversity is a critical factor in enhancing not just the quality of a firm's leadership and decision making, but also it is generally financial, ecological, and social and governance presentation, and eventually, the business's sustainability. An increasing unit of research proposes that encouraging more females to managerial positions of the business society and mainly to leadership echelons of publicly held businesses - may lead to improved performance of the organisation. Such a contribution of females may let businesses focus 
more on short-term profit maximisation temporarily and then divert attention towards a long-term goal and remain focused on them (Lepeley, Pizarro \& Mandakovic, 2015). This eventually creates a positive impact on the overall environment and develops social governance in a better way. Research also proposes that companies perform extraordinarily on comprehensive measures of corporate presentation when gender diversity is openly acknowledged and esteemed.

A considerable review of the extant base of literature discovered that female managers were cooperative and willing to involve in consensus-development (Sims and Morris, 2018). Females' leaders are likely to involve successful in challenging situations and social matters that challenge modern businesses. Female directors are capable enough to adopt inclusive and collaborative measures relating to strategic decision making processes, spend enough time to come across the perfect resolution and are talented to balance out different interests of stakeholders and reach a final conclusion that secures everyone's interest.

\section{Women Bring in Innovative Ideas to Follow Future Growth Trajectory}

Female directors might bring in a fresh perspective to decision making. With more females in top managerial levels, the study proposes that business entities can move from short-run profit maximization to a broad focus on long-term goals. Board levels that consider the role of females are more expected to make choices that bring in large but belated awards, and to support reimbursement linked with long-lasting achievement (Jain $\&$ Pande, 2015). Firms with female membership in board meetings are more expected to look for future growth in the long run and defend their 'license to function' by means of attempts to aid the weak part. For instance, business enterprises in the USA run by females were less expected to use contractual based workers and impermanent employees in the current recessionary phase. In Norway, another example, when the share of business leaderships maintained by females increased from $18 \%$ to $40 \%$ by 2009 , shortterm business profit margin decreased by nearly 4 percent levels as an outcome of some layoffs and high comparative employment (Misra, 2013). On the other hand, such companies did not face low profit margins when they were analysed three years later.

\section{Bring in Innovation to Open New Market Opportunities}

Progressive managers should bring in innovation to successfully target a fast-growing sustainable marketplace and deal with the direst issues across the globe. A current study of McKinsey discovered that $44 \%$ of business managers who followed sustainability mentioned growth and new business options as rationales to deal with issues relating to sustainability (Sims and Morris, 2018). An increment in the number of females on leadership squads has revealed to improve the innovation capability of their firms, particularly when dealing with sensitive matters. There is ample substantiation that confirms that females are quick to recognise critical aspects in newfound technologies, 
revamp existing business models, launch new products and services to cater to client needs whilst also playing an important role to deal with social challenges effectively (Jain \& Pande, 2015).

\section{Encourage Transparency to Support Corporate Governance}

Firms with more females on board levels tend to have improved transparency and a strong business governance framework. Female-driven firms are assumed to perform more ethically and involve in less unethical activities. They also initiate robust governance frameworks, enhance attempts to control management and show high degrees of openness and candidness. Female managers maintain ethical practices within business activities and implement protocols, rules, programs and clear-cut procedures to banish unethical business activities. Firms with female leaders come across serious litigations or large-level controversies (Papadopoulos \& Heslop, 2014). They act as role models for others and lead the market with strong ethical conduct.

\section{Sound Ecological Management to Deal with Risks}

Female managers have been demonstrated to prioritize ecological concerns, adopting practical measures to deal and enhance the energy-effectiveness of their firm's operations and deal with the ecological risks within their business choices. Business enterprises having females on their boards are more expected to determine their goods' carbon releases and to execute measures with dealers to decrease the emission of carbon dioxide gas all through the value chain. They incorporate climate change impacts into their actuarial model while creating goods to aid clients to manage related risks (De Vita, Mari \& Poggesi, 2014). Female leaders always attempt to look forward to environment management and actively work to alter client demand. The more gender balance on the managerial group, the more expected the organisation is to spend in renewable power creation programs, low carbon items, and energy efficient. To emphasise a robust public sector case, a current study reveals females in the United States House of Representatives have constantly voted out their male groups on ecological safety from 2006 till 2015.

\section{Inspirational Examples of Women in International Business}

There are many inspirational examples of females in the international business arena. Gabrielle Giffords was born in Arizona and is a retired participant of the American House of Representatives. A murder effort on her life was made in a public gathering with her people. Even though she got fired in a hard, she phenomenally survived and has gained again her capacity to talk, move, and do routine activities of life (Business.org, 2019). Chelsea Clinton is also a great example since she serves the position of chairperson of a company that looks to improve worldwide health and develop growth opportunities for females so that they become financially stable as well as independent. She is also a member of the board of directors of IAC. 
Jessica Alba was born in California and an award-winning performer. She is a founder of Honest Company, which is a fast-moving consumer product firm that focuses on domestic goods and supply in the market of ethical consumers. Her organization is predicted to be the net worth of 1.7 billion dollars. Sara Blakely, another inspiring female leader, is a billionaire business-minded female and founder of Spanx. She was also listed in Forbes Magazine as the most powerful female in 2016 and was considered as selfmade females in 2017. Lisa Davis is also a great female who serves the position of CEO at Siemens Company. She was in the ninth position of the most powerful lady in the world in 2017 (Business.org, 2019). Angela Ahrendts is the vice president at Apple and formerly served at the position of CEO of Burberry. She was also named as the strongest lady in 2017 and held a position in the list of most inspiring women in the technology world (Business.org, 2019).

\section{Problems Women Face in International Business Limited Financial Support}

Not all business-minded people are lucky enough to have financial support or investor for their enterprise or venture. Some have to bootstrap their commercial projects, depend on credit cards or lift up capital on their own. Females usually face this issue in international business and they greatly lack funding to run a successful venture on their own. It is also general for them to be ignored due to cultural as well as gender differences - several institutes are inclined to support man-run business ventures (Ramadani et al., 2013).

\section{Maintain Proper Balance between Personal and Professional Responsibilities}

A greater part of females are not just business-minded or career-oriented individuals they have family circles, partners, and other household duties. Demands from individual and work-related commitments can pressurize a female to leave wither her venture or closed ones. The domestic life anticipates her to become a role model in the form of a mother and a great wife. On the other hand, the business demands her to become the best leader and exhibit greater commitments and dedication towards the achievement of organizational goals (Allen \& Truman, 2016). It seems challenges for those who do not have a proper social support system since they have to shoulder the entire load by themselves. Some females can harmonize these two lives (personal and professional), while others are disturbed.

\section{Feeling of Failure}

Running an international business is challenging and involves unpredicted situations. Never create a feeling of fear or terror; one would never attempt if they have this sort of emotion. No one enters into an international business with a certainty of 100 percent success. Fear of the identified and the unidentified is a key dilemma for females. They are less inclined towards failing aspects, mainly if the people close to them were doubtful of their skills in international business (Ramadani et al., 2013). This emotion is lethal and 
dangerous since they might end up running from a point of fear in place of confidence. As a consequence, they would fall short in an international business venture when they were intended to become successful.

\section{Pakistani Scenario}

According to UNDP Human Development Reports (2018) share of women in senior and middle management is only $4.2 \%$ which is even less than the region average. Although many women are participating in trade and business related activities including the role in senior and middle management but still participation is negligible. Such numbers indicate that the society is dominated by males where they take the lion's share. In Pakistan women face difficulty in entrepreneurial activities in socioeconomic spectrum. Majority of the women are employed in agriculture sector, or other low paid seasonal labour (Tanwir \& Sidebottom, 2019).

\begin{tabular}{|c|c|c|c|}
\hline Dataset: & Country Profile & & \\
\hline Country: & Pakistan & & \\
\hline Subject & Indicator & Year & Value \\
\hline \multirow[t]{4}{*}{$\begin{array}{l}\text { Population and } \\
\text { labour force }\end{array}$} & $\begin{array}{l}\text { Share of adult population with advanced } \\
\text { education }(\%)\end{array}$ & 2018 & 8.4 \\
\hline & Labour force participation rate $(\%)$ & 2018 & 51.0 \\
\hline & Labour force participation rate, men (\%) & 2018 & 80.4 \\
\hline & Labour force participation rate, women (\%) & 2018 & 21.9 \\
\hline \multirow[t]{7}{*}{ Employment } & $\begin{array}{l}\text { Female share of employment in senior and middle } \\
\text { management }(\%)\end{array}$ & 2013 & 4.2 \\
\hline & Employment-to-population ratio (\%) & 2018 & 48.9 \\
\hline & Employment-to-population ratio, men (\%) & 2018 & 77.2 \\
\hline & Employment-to-population ratio, women (\%) & 2018 & 20.9 \\
\hline & Share of agriculture in total employment $(\%)$ & 2018 & 37.4 \\
\hline & Share of industry in total employment (\%) & 2018 & 25.0 \\
\hline & Share of services in total employment $(\%)$ & 2018 & 37.6 \\
\hline \multirow{4}{*}{$\begin{array}{l}\text { Unemployment } \\
\text { and labour } \\
\text { underutilization }\end{array}$} & Time-related underemployment rate (\%) & 2018 & 0.7 \\
\hline & Unemployment rate $(\%)$ & 2018 & 4.1 \\
\hline & Unemployment rate, men $(\%)$ & 2018 & 4.0 \\
\hline & Unemployment rate, women $(\%)$ & 2018 & 4.6 \\
\hline \multirow[t]{6}{*}{ Youth } & Youth labour force participation rate (\%) & 2018 & 40.0 \\
\hline & Youth labour force participation rate, men $(\%)$ & 2018 & 61.3 \\
\hline & Youth labour force participation rate, women (\%) & 2018 & 18.3 \\
\hline & Youth unemployment rate $(\%)$ & 2018 & 7.9 \\
\hline & Youth unemployment rate, men (\%) & 2018 & 8.2 \\
\hline & Youth unemployment rate, women (\%) & 2018 & 6.8 \\
\hline
\end{tabular}




\begin{tabular}{|c|c|c|c|}
\hline & $\begin{array}{l}\text { Share of youth not in employment, education or } \\
\text { training (NEET) }(\%)\end{array}$ & 2018 & 31.0 \\
\hline & $\begin{array}{l}\text { Share of youth not in employment, education or } \\
\text { training (NEET), men (\%) }\end{array}$ & 2018 & 7.6 \\
\hline & $\begin{array}{l}\text { Share of youth not in employment, education or } \\
\text { training (NEET), women }(\%)\end{array}$ & 2018 & 54.9 \\
\hline \multirow[t]{2}{*}{ Working time } & $\begin{array}{l}\text { Share of employees working more than } 48 \text { hours } \\
\text { per week }(\%)\end{array}$ & 2018 & 35.2 \\
\hline & $\begin{array}{l}\text { Mean weekly hours actually worked per employed } \\
\text { person }\end{array}$ & 2018 & 47 \\
\hline \multirow[t]{3}{*}{$\begin{array}{l}\text { Earnings and } \\
\text { labour income }\end{array}$} & $\begin{array}{l}\text { Average monthly earnings of employees (local } \\
\text { currency) }\end{array}$ & 2018 & 19270 \\
\hline & $\begin{array}{l}\text { Average monthly earnings of employees, } \\
\text { manufacturing (local currency) }\end{array}$ & 2018 & 17363 \\
\hline & Gender wage gap $(\%)$ & 2018 & 23.7 \\
\hline \multirow[t]{4}{*}{$\begin{array}{l}\text { Social } \\
\text { protection }\end{array}$} & $\begin{array}{l}\text { Percentage of health care expenditure not financed } \\
\text { by private households' out of pocket payments }(\%)\end{array}$ & 2011 & 37.0 \\
\hline & $\begin{array}{l}\text { Public social protection expenditure [all functions] } \\
\text { as a percent of GDP }(\%)\end{array}$ & 2009 & 1.7 \\
\hline & $\begin{array}{l}\text { Public social protection expenditure [excluding } \\
\text { health care] as a percent of GDP }(\%)\end{array}$ & 2010 & 1.3 \\
\hline & $\begin{array}{l}\text { Active contributors to an old age contributory scheme } \\
\text { as a percent of the working-age population }(\%)\end{array}$ & 2009 & 3.1 \\
\hline \multirow[t]{2}{*}{$\begin{array}{l}\text { Safety and } \\
\text { health at work }\end{array}$} & $\begin{array}{llll}\begin{array}{l}\text { Non-fatal occupational injuries } \\
\text { workers }\end{array} & \text { per } 100^{\prime} 000 \\
\end{array}$ & 2018 & 1136 \\
\hline & Days lost per occupational injury & 2018 & 1659339 \\
\hline $\begin{array}{l}\text { Industrial } \\
\text { relations }\end{array}$ & Trade union density rate $(\%)$ & 2008 & 5.6 \\
\hline
\end{tabular}

Source: International Labour Organization, ILOSTAT https://ilostat.ilo.org/data/countryprofiles/

\section{Methodology}

The research methodology employed for this research is qualitative, using descriptive nature and analyzing the secondary data to understand the core concept of the study with the help of interpreting, reanalyzing and reviewing the data from reliable resources and make informed recommendations to understand the Role of Women in, Trade, Management and International Business. As in today's world women's role cannot be neglected or underestimated. In International Business and trade women are not only contributing but leading some multinationals. In order to analyze and understand the topic and draw conclusions numerous past and contemporary researches are taken for review and to draw conclusions based on the data. 


\section{Findings}

We have learnt that social norms being the base cause of gender discrimination. In order to address this issue, economic growth plays a very important role in minimizing barriers towards gender equality and social norms. Different studies have discovered a strong relationship among gender equality and economic growth.

Gender equality is a universal goal that is enshrined in many international instruments such as the Charter of the United Nations, the Universal Declaration of Human Rights (1948) and the Convention on the Elimination of all Forms of Discrimination Against Women (CEDAW), 1979.

A gender analysis of trade and trade liberalization in developing countries reveals some interesting facts:

(a) An increase in trade and investment in the labour-intensive sectors of goods and services markets has provided numerous employment opportunities to women, in both the formal and informal segments of the labour market. In agrarian economies, however, when import expansion has displaced domestic production, women often have to bear the brunt of the costs of adjustment. According to International Labour Organization (2019) A Quantum Leap for Gender Equality, share of women in managerial positions by region 2018 is as below:

World Average is 27.1\%, Americas 39.0\%, Europe and Central Asia 34.4\%, Asia and the Pacific $22.5 \%$, Africa $22.3 \%$, Arab states $11.1 \%$. This clearly shows the gender disparity in all regions of the world but Arab States and Asia and the Pacific in particular where the gender gap in managerial position is evident and can only be bridged by giving more opportunities to women.

(b) A large and cheap female labour surplus has often provided the competitive edge for the export-oriented and labour-intensive industries in developing countries. Conditions of work for women in these sectors have not always been good. This cheap-labour policy has not contributed to closing the wage gap between men and women. In hardly any country in the world have global market forces reduced gender-based wage differentials. Moreover, in countries which have succeeded in moving up the technology ladder, the female labour force has tended to lose importance, as women have become more disadvantaged in terms of technical qualifications. Oxfam (2020) reports that men hold 50\% more wealth than women in the world, similarly men have more land, shares and assets even in some countries' laws prevent women's ownership. It is not only a clear bias and favour to men but also depriving women of their equal rights. This limits majority of women to poorly paid and uncertain employments. Globally only $18 \%$ of Ministers and $24 \%$ of Parliamentarians are women. Economic empowerment of women is necessary on war footing basis to bring them up this ladder. 
(c) Inorder to enhance the efficiency and competitiveness between trade and gender (specifically females), Liberalization of services and jobs in particular, has the potential of enhancing the efficiency and competitiveness Gender economies. There are risks associated with liberalization of service as well as it can create inequities to basic resources and mis use of things too UNCTAD (2016b).

(d) As Pakistan is mainly an agrarian economy therefore inorder to promote women through Multilateral trade commitments and agreements which can affect women and gender equality in different ways: in securing market access in sectors where women are dominant; in potentially affecting government export promotion programmes to help businesses owned by women.

\section{Conclusions}

To sum up, the current report has made an attempt to highlight the role of women and their contribution to international business, management and trade. The landscape of corporate employment has changed now, and one can observe drastic changes since now more and more females are becoming part of a global workforce.

\section{Inequality based World Economic System}

It is evident from facts that the World Economic system is based on inequality where both genders are not given equal opportunities. According to OXFAM (2020b) combined wealth of the 22 richest men in the world is more than the wealth owned by the entire women population of Africa. They are striving hard to face the tough competition of the international business world and assume leadership positions while directing their male counterparts. The report has made an attempt to underline the role of women and how they face problems in this long journey of success. Some examples of inspirational female leaders are also given that is the role model for young females who are careeroriented and look forward to running their own business in the near future. It is the right time to support them and develop positive avenues for them so that they can also actively support the nation's economy and become a productive part of society. Another alarming fact in the Oxfam report is regarding the unpaid work women are involved or delved in unpaid care work done by women that amounts to $\$ 10.8$ trillion which is three times the size of world tech industry. This care work includes childcare, patients care of physically and mentally challenged individuals, domestic chores including cooking, cleaning, fetching water and firewood. All this care work is unaccounted and includes minimum or no wage, while most of the domestic workers worldwide are also women and that is again one of the underpaid professions.

\section{The Business Case for Diversity is Strong}

A study by Boston Consulting Group (BCG, 2017) of 171 German, Swiss and Austrian businesses showed a clear relationship between diverse management teams and revenues 
from innovative products and services. It also showed that innovation performance only increased significantly when more than $20 \%$ of management positions were held by women.

- No country can benefit from diverse leadership until gender bias in recruitment and development is eliminated. Women are still experiencing gender discrimination when applying Role of Women in International Business, Management \& Trade or being interviewed for a job. Add to this bias in talent identification and hiring sources, and its little surprise that, $26 \%$ of women cited access to both internal and external networking as a barrier to advancement. An increase level of female education would lead to more employed women. In South Asia and Africa around $60 \%$ of employed women are associated with agriculture sector (ILO, 2016b)

- Once female talent is recruited, it needs to be retained. Employers need to devise policies that include but do not limit to paid parental leave, flexible hours, part-time working and remote working. Research by Catalyst Beninger and Carter, 2013) reveals that $83 \%$ of women with access to Flexible Working Arrangements (FWA) aspired to reach the executive level, versus $54 \%$ of those without. Numerous women would prefer not to be the subject of unique treatment or quotas, yet that what they do require are adaptable solutions for oversee work and family responsibilities.

These conclusions are drawn from the data analysed through different reliable sources and it shows a clear and evident picture of in equal treatment of women in International Business, Trade and Management around the globe. Prime objective of the study was to highlight and bring together all the facts related to the topic so that a comprehensive document is formed to look at the contribution and potential of women in the world, where most of the work done by women is either underpaid or unpaid. This system of inequality needs to be reviewed and changed so that women play their part true to their potential and are acknowledged and credited for the work they perform and above all be given equal chances like men in all fields without any discrimination.

\section{Recommendations}

Based on the study, the review of different literature and analysing the data, it can be stated that role of women in trade and business activities cannot be neglected and to overcome problems faced by women in international businesses, there are some recommendations that are practical enough to be followed and implemented across countries and different regions of the world. It is suggested for developing as well as developed nations of the world to support female and encourage them to become part of the labour force. Training programs must be designed by governments that intend to develop entrepreneurship skills among deserving females of the nation (Jain \& Pande, 2015). Countries need to develop learning programs for females so that they can learn about business skills and show their talent in the near time. This seems a great suggestion 
for countries to support female involvement and empower them to take their decisions and work in their own capacity. Moreover, females who have talent but due to limited funding are not able to start their own venture and look forward to some amazing opportunities, they must get encouragement and finances to make their dreams come true. It is a suitable time to unleash the potential buried in them. It is also the right time and the government should invest in female education and support them in learning sophisticated skills that would help them to run future ventures.

Along with these suggestive measures, trade policies must be flexibly designed and adjust the needs of both males and females. Equal opportunities must be provided to both genders so that they can compete in a healthy manner. Trade policies must enable females to work in a relaxed manner without having a fear of sexual harassment or bullying. Effective trade policy in this context would be that they make international businesses and workplaces safe and secure for female workers. There is a dire need to consider female protection when designing a better trade policy for international ventures. Gender equality is one of the agenda of 2030 Sustainable Development Goals and they should be implemented worldwide in developing and developed world likewise

\section{References}

Allen, S. \& Truman, C., 2016. Women in Business: Perspectives on Women Entrepreneurs. Routledge, pp.53-76.

Boston Consulting Group, 2017. The Mix that Matters: Innovation through Diversity, http://media-publications.bcg.com/22feb2017-mix-that-matters.pdf. Accessed on December 17, 2019.

Bencko, C. \& Pelster, B. (2013). How Women Decide. Harvard Business Review, pp.2-6.

Beninger, A. \& Carter, N. (2013). The Great Debate: Flexibility vs. Face Time - Busting the Myths Behind Flexible Work Arrangements, Catalyst Research Center, p-6.

Bollen, Y. (2018). EU Trade Policy. Handbook of European Policies. Edward Elgar Publishing, pp.22-28.

Brenton, P., Gamberoni, E. \& Sear, C. (2013). Women and Trade in Africa: Realizing the Potential. World Bank. Washington, D.C.: pp.115-128.

Business.org (2019). 70 Inspirational Women Impacting the World - 2018 | Business.org. Available at: https://www.business.org/business/startup/most-inspirationalwomen-leaders/ Accessed 7 Dec. 2019]. 
Bussolo, M. \& Hoyos, R. (2009). Gender Aspects of the Trade and Poverty Nexus: A Macro-Micro Approach. World Bank,pp-34-38.

Caraway, T.L. (2007). Assembling Women: The Feminization of Global Manufacturing. ILR Press. Ithaca, pp.113-120.

Carter, D. A., Simkins, B. J. \& Simpson, W. G. (2013). Corporate Governance, Board Diversity and Firm Value. Financial Review, vol.38:6, pp.33-53.

Cook, A. \& Glass, C. (2014). Women and Top Leadership Positions: Towards an Institutional Analysis. Gender, Work \& Organization, vol.21:1, pp.91-103.

Davies, P.W. (2016). Current Issues in Business Ethics. Routledge.

De Vita, L., Mari, M. \& Poggesi, S. (2014). Women Entrepreneurs in and from Developing Countries: Evidences from the Literature. European Management Journal, vol.32:3, pp.451-460.

Elliott, K. (2016). The Global South Takes the Lead on Gender Sensitive. Trade Policy, Center for Global Development.

Epstein, C.F. \& Coser, R.L. eds. (2018). Access to Power: Cross-National Studies of Women and Elites. Routledge.

Friel, S., Gleeson, D., Thow, A.M., Labonte, R., Stuckler, D., Kay, A. \& Snowdon, W. (2013). A New Generation of Trade Policy: Potential Risks to Diet-Related Health from the Transpacific Partnership Agreement. Globalization and Health, vol.9:1, p.46.

GIZ. (2014). Trade and Gender - Exploring a Reciprocal Relationship. Author: Markéta von Hagen.

International Labour Organization, 2019, A Quantum Leap for Gender Equality, p.28.

International Labour Organization, ILOSTAT https://ilostat.ilo.org/data/country-profiles/. Accessed on January 19, 2020.

International Labour Organization, (2016b), Women at Work Trends, p-23.

International Monetary Fund, 2018, Pursuing Women's Economic Empowerment, pp.5-8. https://www.imf.org/en/Publications/Policy-Papers/Issues/2018/05/31/pp053118 pursuing-womens-economic-empowerment. Accessed on December 14, 2019. 
Jain, N. \& Pande, S. (2015). Impediments and Solutions to Entry of Women as Leaders in the Workplace. Indian Journal of Public Administration, vol.61:2, pp.294-302.

Jobes, K. (2010). Presentation: Expanding Trade: Empowering Women. Are We Missing a Trick? Why Gender Matters for Trade? World Bank, Washington, DC.

Joy, L., Carter, N. M., Wagner, H. M. \& Narayanan, S. (2007). The Bottom Line: Corporate Performance and Women's Representation on Boards', Catalyst.

Lepeley, M.T., Pizarro, O. \& Mandakovic, V. (2015). Women Entrepreneurs in Chile: Three Decades of Challenges and Lessons in Innovation and Business Sustainability. In Female Entrepreneurship in Transition Economies (pp. 247264). Palgrave Macmillan, London.

Lippoldt, D., (2013). Policy Priorities for International Trade and Jobs (No. 963-201674946). https://www.oecd.org/site/tadicite/50258009.pdf

McElhaney K. A. \& Mobasseri S., 2012. Women Create a Sustainable Future. UC Berkeley Haas School of Business. https:/www.eticanews.it/wp-content/uploads/ 2012/11/Report-Women_Create_Sustainable_Value.pdf

Misra, N., 2013. Sustainable energy for all: Empowering women. UN Chronicle, 52(3), pp.20-22.

Noland, M., Moran, T. \& Kotschwar, B. (2016). Is Gender Diversity Profitable? Evidence from a Global Survey, Working Paper16-3. Institute for International Economics.

Oxfam (2020). Time to Care: Unpaid and Underpaid Care Work and the Global Inequality Crisis, https://oxfamilibrary.openrepository.com/bitstream/handle/10546/620928/ bp-time-to-care-inequality-200120-en.pdf . Accessed on January 14, 2020.

Oxfam, (2020b). Time to Care: Unpaid and Underpaid Care Work and the Global Inequality Crisis, p.8. https://oxfamilibrary.openrepository.com/bitstream/handle/ 10546/620928/bp-time-to-care-inequality-200120-en.pdf. Accessed on January 14, 2020.

Papadopoulos, N. \& Heslop, L.A. (2014). Product-Country Images: Impact and Role in International Marketing. Routledge.

Ramadani, V., Gërguri, S., Dana, L.P. \& Tašaminova, T. (2013). Women Entrepreneurs in the Republic of Macedonia: Waiting for Directions. International Journal of Entrepreneurship and Small Business, vol.19:1, pp.95-121. 
Sims, C.M. \& Morris, L.R. (2018). Are Women Business Owners Authentic Servant Leaders? Gender in Management: An International Journal, vol.33:5, pp.405-427.

Tanwir, M. \& Sidebottom, R. (2019). The Trade and Gender Nexus in Pakistan. Journal of International Women's Studies, vol.10:2, p-136.

UNCTAD (2016). Trade, Gender and Development. Advocating Inclusive and GenderSensitive Economic Development on a Global Level. http://unctad.org/en/PublicationsLibrary/ditcmisc2016d6_en.pdf. Accessed on December 11, 2019.

UNCTAD (2016b). Trade as a Tool for the Economic Empowerment of Women. https://unctad.org/meetings/en/SessionalDocuments/ciem8d2_en.pdf. Accessed on December 23, 2019.

UNDP Human Development Reports, 2018. http://hdr.undp.org/en/countries/profiles/ PAK\#. Accessed on November 19, 2019.

Van Staveren, I. (2007). Gender Indicators for Monitoring Trade Agreements, WIDE Briefing Paper.

WEF (2017). World Economic Forum, Global Gender Gap Report.

World Health Organization (2014). Accelerating Nutrition Improvements (ANI): Mapping of Stakeholders and Nutrition Actions in Three Scaling-Up Countries in SubSaharan Africa: Report of a Meeting, 27-28 February 2014, Addis Ababa, Ethiopia.

World Trade Organization (2017). Buenos Aires Declaration on Women and Trade Outlines Actions to Empower Women. https://www.wto.org/english/news_e/ news17_e/mc11_12dec17_e.htm. Accessed on December03, 2019.

Farrukh Naseem Qureshi is Lecturer in the Shaheed Zulfiqaar Ali Bhutto Institute of Science Technology, Karachi, Pakistan.

Tehreem Farrukh is an Assistant Professor in the School of Law, University of Karachi, Karachi, Pakistan. 